\title{
Prediction Soil Bulk Density and Moisture Constants Using Particle Size Distribution for Selected Libyan Calcareous Soils
}

\author{
Ahmed Y. Habel ${ }^{1}$
}

\begin{abstract}
The most developed Pedotransfer Functions $\left(\mathrm{PTF}_{\mathrm{s}}\right)$ for estimating the soil bulk density use data on soil texture and organic matter content as independent variables, as well as the majority published $\mathrm{PTF}_{\mathrm{s}}$ for predicting the soil moisture constants involved soil texture, bulk density, and organic matter as independent variables. On a regional scale as in Libya where the organic matter content is spare, as a result of the prevailed climatic conditions, the parameterization of these equations will be difficult. So, the objective of this work is studying the interrelations between soil texture and these parameters, and the possibility of access correlations for developing regression equations. For the purpose of estimating the bulk density and soil water constants from accessible routinely data such as soil texture as an independent variable, 46 soil samples were collected from Al Izzayat area ( Region of Al Jabal Al akhdar) as a training set, and 12 soil samples, as a test set from Mikilli area, which are characterized with the same environmental conditions to the training area. The obtained $\mathrm{PTF}_{\mathrm{s}}$ equations are characterized with highly satisfied predicted coefficients of determinations $\left(R_{p}^{2}\right)$. The validation of these derived equations was done successfully with calculated coefficients of determination $\left(R^{2}\right)$. The $\mathbf{R}^{2}$ values were $93.8 \%$ for field capacity, $92.2 \%$ for bulk density, $91.3 \%$ for permanent wilting point, and $71.7 \%$ for available water capacity. These variations were more related to sand and silt contents rather than clay content in the investigated samples.
\end{abstract}

\section{INTRODUCTION}

Libya has a surface area of approximately $1,750,000$ $\mathrm{Km}^{2}$ and is classified as arid region, which are distinguished by water scarcity and highly variable precipitation, covers only $7 \%$ of total surface area of the country (Elfadli 2009).

As a result to this fact, most of the Libyan soils are characterized by relatively a sparse vegetative cover, low organic matter content and high salinity level and sodicity of soils (Selkhozprom, 1980). This led to poor its structure and hydraulic properties. Entisols ,Inceptisols, Aridsols and Alfisols are dominant soils orders in the eastern region of Libya with a limited occurrence of Mollisols in certain regions of the mountains, where the annual average precipitation rates may exceed $400 \mathrm{~mm}$ (Ben Mahmoud, 1995).
For understanding the physical properties of these soils is essential to formulate sound water management strategies. Generally speaking, the information of physical properties, especially the water retention and infiltration rates of these soils on the whole are scanty (Dzymala, 1995). Some direct measurements of the physical and chemical properties of soils are impractical for most research and management, especially the methods of estimation of the soil properties are time consuming and expensive (Walczak et al., 2002; Budiman et al., 2011). Furthermore, due to high temporal and spatial variability in soil's properties, large numbers of soil samples are required for characterizing the real field conditions (Oyedele et al., 2010). To work out these problems, an alternative measurement is to estimate these properties using as predictors more easily, inexpensively and routinely measured soil property such as particle size distribution (Saxton et al., 1986; Zhuang et al., 2001). This method can be called Pedotransfer Functions $\left(\mathrm{PTF}_{\mathrm{S}}\right)$, which are a multiple regression equations between soil properties. They allow the possibility of translating the existing surrogate data into a data which we need (Bouma, 1989; Wosten et al.,2001; Baker et al. 2008). In last decades, many attempts have been made to evaluate the general applicability and prediction accuracy of $\mathrm{PTF}_{\mathrm{S}}$ developed to predict soil physical properties such as bulk density, field capacity, wilting point and soil water retention characteristic curve (Walczak R. et al., 2002; Kalman R. et al., 2004; Bruno et al., 2005; Duan X. et al., 2010; Ghanbarian A. et al., 2010; J.M.Hollis et al., 2012). Most of these developed $\mathrm{PTF}_{\mathrm{S}}$ for the estimation of the bulk density and the hydraulic properties employed the particle size distribution and the organic matter content as predictors. Because of the lack in the organic matter content in most of the Libyan soils. The suggested models will neglect organic matter content as input in this case (Zacharias et al. ,2007).

Present work was carried out to generate basic data for some Libyan soils orders using $\mathrm{PTF}_{\mathrm{S}}$ and predict the important physical properties, which may play a significant role on their utilizes, based on accessible soil physical properties in the study area.

\footnotetext{
${ }^{1}$ Soil \& Water Department, Faculty of Agriculture

Omar Al Mukhtar University, El- Bieda - Libya

Received Febuary 14, 2013, Accepted March 26, 2013
} 


\section{MATERIALS AND METHODS}

\section{a. Training site description}

The investigations were carried out at $\mathrm{Al}$ Izziyat ( $\mathrm{Al}$ Jabal Alkhdar region) which has an area about 1325 hectares, situated between latitudes of $32^{\circ} 07^{\circ}$ and $32^{\circ}$ $09^{\prime} \mathrm{N}$ and longitudes of $22^{\circ} 40^{\prime}$ and $22^{\circ} 42^{\prime} \mathrm{E}$ (Fig. 1). Climatically, the mean values of the monthly temperature vary between $11^{\circ} \mathrm{C}$ in January and $28^{\circ} \mathrm{C}$ in July with mean annual temperatures of $20^{\circ} \mathrm{C}$. The annual rainfall mean about $55 \mathrm{~mm}$ and is practically absent during summer season (June-September). Hence, the climatic nature of the studied area is that of pre-desert zone. The land is entirely located on alluvial sediments made up mostly of silt-loamy soils or finer materials, especially in the subsoil and, subordinately, of sandloam soils. The substratum is generally made of small and coarse pebbly alluvial, resting on bedrock which being made up of limestone.

\section{b. Laboratory and statistical analysis}

Forty six soil samples were collected from the upper layer $(0-30 \mathrm{~cm})$ at the study area. All these soil samples were processed and analyzed for various physicochemical properties using standard methods; the particle size distribution and bulk density of soil samples were determined by the hydrometer and cylinder methods respectively (Klute ,1986a). As for the Organic Matter and calcium carbonate contents were measured by using Walkley-Black and the Calcimetry methods respectively (Klute, 1986b). The moisture contents at field capacity and wilting point were determined with a pressure plate apparatus at -33 and $-1500 \mathrm{kPa}$, respectively. Available water in the soils was computed by subtracting the amount of water held at $1500 \mathrm{kPa}$ from that at $-33 \mathrm{kPa}$ (Klute, 1986a).

The statistical analyses were produced to evaluate the descriptive statistical parameters such as the minimum, the maximum, the mean, standard deviation and coefficient of variation. In the meantime, for the sake of understanding the strength and the kind of linear dependence between the measured soil properties, the coefficients of correlation (r) were calculated. On the other hand Coefficients of Determination $\left(\mathrm{R}^{2}\right)$ were calculated to consider how far these variables are dependent or not from each other. Towards developing the Pedotransfer Functions $\left(\mathrm{PTF}_{\mathrm{S}}\right)$ to estimate the bulk density, field capacity and permanent wilting point, typical regression equations were obtained using these parameters as dependent variables, where as the particle size distribution was considered as independent variables (Equation 1).

$$
\mathrm{Y}=\mathrm{a}+\mathrm{b} \mathrm{X}_{1}+\mathrm{c} \mathrm{X}_{2}+\mathrm{dX} \mathrm{X}_{3}
$$

Where: $\mathrm{Y}$ response variable, $\mathrm{X}_{1}$ sand Fraction, $\mathrm{X}_{2}$ silt fraction, $\mathrm{X}_{3}$ clay fraction and $(\mathrm{a}, \mathrm{b}, \mathrm{d})$ regression coefficients.

Predicted Determination Coefficient $\left(\mathrm{R}_{\mathrm{p}}^{2}\right)$ was used as judging tool to indicate how well the developed models predict responses for these observations, as well as can prevent over fitting the models.

In order to verify the validity of the developed models, fourteen soil samples were collected from Mikilli West area, situated at $32^{\circ} 06^{\prime} \mathrm{N}$ and $22^{\circ} 17 \mathrm{E}^{\prime}$ (Figure 1).This area is to some extent similar in the environmental conditions to the training site. It is an alluvial origin and made up of deposits belonging to sandy soils characterized by the presence of gravelly horizons and loamy or silty soils especially in the flat areas. The test set soil samples were processed under the laboratory analysis as was done with the training set.

All the statistical works in this research were conducted using The Statistical Software Minitab Version 16 (2011).

\section{RESULTS AND DISCUSSIONS}

Table 1\&2 represents range, mean, standard deviation and coefficient of variation of selected physical and chemical properties of the studied soil samples. All parameters show a considerable difference except soil bulk density. This ample variation is favorable and necessary for the generation of pedotransfer functions (Pachepsky et al., 1999). Also, this variation will impart a greater possibility to make the developed Pedotransfer Functions to be applied with more reliability to the other soils under the same environmental conditions.

Generally, we may summarize that both the training set and test set samples have a silty loam texture with low organic matter content and high calcium carbonate content. The depression in the organic matter content may be interpreted by the climatic conditions which dominate in this area, as well as, by the role of calcium carbonate content in enhancing the decomposition of the organic matter (Kishchuk, 2000).

\section{a. Bulk Density (BD)}

The soil bulk density, an important soil physical parameter, is usually determined by most soil specialists to be used in models to characterize the field conditions; as indicator of soil compactness and aeration status or to convert to volumetric measurements (Bruno et al., 2005). Table 3 illustrates, sand content showed a significant high positive correlation with BD (0.938), which means the tendency of the soil to be denser as the texture is sandier; that can be interpreted by the soil particles packing (Hillel 2004). 


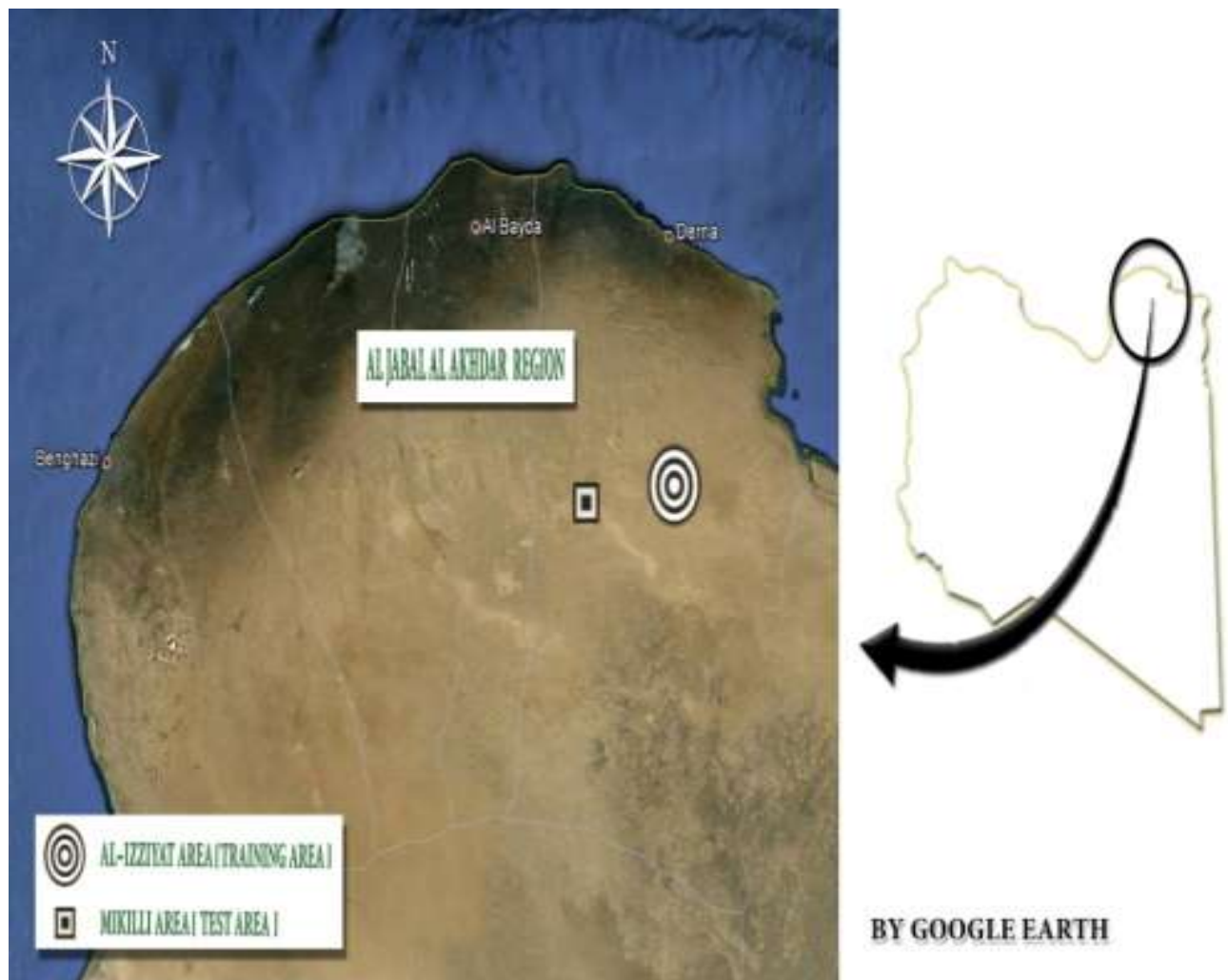

Fig. 1. The location of the study area

Table 1. Descriptive Statistics of training samples $(n=46)$

\begin{tabular}{|c|c|c|c|c|c|}
\hline Soil Property & Minimum & Maximum & Mean & St. Deviation & C.V \% \\
\hline Sand (S) \% & 2.0 & 85.0 & 29.34 & 20.27 & 69.10 \\
\hline Silt (Si) \% & 12.9 & 77.1 & 55.63 & 16.45 & 29.56 \\
\hline Clay (C) \% & 2.1 & 39.9 & 14.60 & 7.29 & 49.94 \\
\hline Bulk Density (BD) ${\mathrm{Mg} . \mathrm{M}^{-3}}^{3}$ & 1.15 & 1.5 & 1.27 & 0.08 & 6.66 \\
\hline Organic Matter content (OM) \% & 0.4 & 2.02 & 0.90 & 0.41 & 44.89 \\
\hline Calcium Carbonate $\left(\mathrm{CaCO}_{3}\right) \%$ & 23.8 & 69.8 & 44.06 & 11.13 & 25.25 \\
\hline Field Capacity (FC) \% & 8.6 & 30.9 & 22.92 & 5.10 & 22.23 \\
\hline Permanent Wilting Point (PWP)\% & 3.8 & 16 & 11.21 & 2.75 & 24.50 \\
\hline Available Water Capacity (AWC) \% & 4.5 & 15.3 & 11.71 & 2.56 & 21.89 \\
\hline
\end{tabular}

Table 2. Descriptive Statistics of testing samples $(n=12)$

\begin{tabular}{lccccc}
\hline Soil Property & Minimum & Maximum & Mean & St. Deviation & C.V \% \\
\hline Sand $(\mathrm{S}) \%$ & 2.3 & 54.8 & 17.42 & 16.07 & 76.15 \\
\hline Silt $(\mathrm{Si}) \%$ & 33.6 & 74 & 59.44 & 11.48 & 19.85 \\
\hline Clay $(\mathrm{C}) \%$ & 11.6 & 33.5 & 23.14 & 7.3 & 34.61 \\
\hline Bulk Density (BD) $\left(\mathrm{Mg.M}^{-3}\right)$ & 1.11 & 1.37 & 1.20 & 0.07 & 6.61 \\
\hline Organic Matter content $(\mathrm{OM}) \%$ & 0.50 & 1.4 & 0.83 & 0.25 & 29.93 \\
\hline Calcium Carbonate $\left(\mathrm{CaCO}_{3}\right) \%$ & 24.8 & 63.8 & 33.51 & 12.84 & 34.35 \\
\hline Field Capacity (FC) \% & 16.4 & 29.5 & 25.99 & 3.95 & 15.6 \\
\hline Permanent Wilting Point (PWP)\% & 8.3 & 16 & 13.12 & 2.22 & 17.64 \\
\hline Available Water Capacity (AWC) \% & 8.1 & 15 & 12.87 & 2.08 & 16.33 \\
\hline
\end{tabular}


Behavior of silt and clay contents under the consideration was as expected; correlated negatively with the measured values of BD (-0.874 and -0.601). Fact that ,clay content was weakly correlated with soil $\mathrm{BD}$ as compared with the silt fraction did; this can be explained by the susceptible of these soils to shrinking -swelling potentials, since there are a long periods of drought.

The relation between calcium carbonate and $\mathrm{BD}$ draws a special attention $(r=0.841)$; where the calcium carbonate have a similar conduct on BD as the sand content did. This may be explained by the slow chemical weathering processes of the calcium carbonate in the area as a response of low precipitation rate.

According to the linear regression analysis (Table 4) Fig. 2a, it is clearly noted, that the BD values is well dependent on the particle size distribution (Archer et al., 1972 ; Bruno et al. 2005); by more degree on the sand content with a goodness of fit $\mathrm{R}^{2}=88 \%$, followed by silt $(76.3 \%)$ and in less degree on the clay content (36.1 $\%)$. On the other hand the role of calcium carbonate should not be disregarded $(70.7 \%)$.

\section{b. Field Capacity (FC)}

Soil moisture retained at the FC is useful for assessing the plant available water, so it has been widely applied in the evaluation and deciding of the amount of water to be applied for recharging the rooting zone to its optimum moisture content for the plant growth, as well as ensuring negligible drainage loss and thus enhancing the applied water use efficiency (Lal, 2006).

It is closely related to soil texture and it is influenced by the organic matter content, types of clay minerals present and soil structure (Troeh et al., 2005).

Because the FC is the soil moisture content retained in the soil pores against the gravitational force; after the drain off excess water, there might be close relation between the soil particles and FC. This can be demonstrated, that the results reveal evident negative correlation coefficient between FC and sand content (-0.914), while they show significant positive correlations $(0.928$ and 0.494$)$ for silt and clay contents respectively (Table 3); this can be interpreted by granting of these fractions the optimum combinations of surface areas and pores. Axiomatically, with an increase in sand content, BD will increase leading to reducing in the pore spaces; thus water retention was less, which resulted as indirect effect of the sand content in reduction of FC values. A respectable negative correlation between calcium carbonate and FC was calculated (-0.774); this may be suggested by the lower adsorption energy by the soil calcium carbonate.

The regression analysis in table 4 \& Fig. 2b, show that, the silt content imparts greater an increasing in the FC values followed in less degree by the clay content $\left(\mathrm{R}^{2}=0.861\right.$ and 0.244$)$. In the opposite direction it is remarkable that the independent variables that influence the FC in the decreasing order were the sand content, BD and calcium carbonate $\left(\left(\mathrm{R}^{2}=0.835,0.766,0.598\right)\right.$.

\section{c. Permanent Wilting Point (PWP)}

The PWP is generally defined as the moisture retained in the soil at matric potential of $-1500 \mathrm{kPa}$, Similar to FC, a high negative correlation coefficients are calculated between PWP, the sand content $(-0.900)$ associated with calcium carbonate $(-0.774)$ and the measured BD (0.866), while positive correlations coefficients were predominated between PWP, silt content, clay content and FC $(0.869,0.536,0.962)$ respectively.

The regression analysis in Table $4 \&$ Fig. 2c allows considering that; the PWP is to some extent significantly dependent upon these parameters, except the clay content which explains variance about $29 \%$ of the PWP values. It is well noted that, the behavior of clay content was similar as in the case of FC; $24.4 \%$ of clay content explains the variance of FC values. This result is matching with Foth (1978), who pointed out that many researchers has shown that the FC and PWP, in the most studied soils be closely linked to the sand and silt contents rather than the clay content.

Table 3. Matrix correlation between the training soil properties

\begin{tabular}{lcccccccc}
\hline \multicolumn{1}{c}{ Parameter } & $\mathbf{S}$ & $\mathbf{S i}$ & $\mathbf{C}$ & $\mathbf{B D}$ & $\mathbf{O M}$ & $\mathbf{C a C O}_{3}$ & $\mathbf{F C}$ & $\mathbf{P W P}$ \\
\hline $\mathrm{Si}$ & $-0.935^{* *}$ & & & & & & & \\
\hline $\mathrm{Cl}$ & $-0.657^{* *}$ & $0.382^{* *}$ & & & & & & \\
\hline $\mathrm{BD}$ & $0.938^{* *}$ & $-0.874^{* *}$ & $-0.601^{* *}$ & & & & \\
\hline $\mathrm{OM}$ & -0.170 & $0.317^{* *}$ & -0.250 & -0.243 & & & \\
\hline $\mathrm{CaCO}$ & $0.883^{* *}$ & $-0.808^{* *}$ & $-0.667^{* *}$ & $0.841^{* *}$ & -0.202 & & & \\
\hline $\mathrm{FC}$ & $-0.914^{* *}$ & $0.928^{* *}$ & $0.494^{* *}$ & $-0.875^{* *}$ & $0.309^{*}$ & $-0.774^{* *}$ & & \\
\hline $\mathrm{PWP}$ & $-0.900^{* *}$ & $0.886^{* *}$ & $0.536^{* *}$ & $-0.864^{* *}$ & $0.323^{*}$ & $-0.772^{* *}$ & $0.962^{* *}$ & \\
\hline $\mathrm{AWC}$ & $-0.852^{* *}$ & $0.895^{* *}$ & $0.407^{* *}$ & $-0.813^{* *}$ & 0.267 & $-0.711^{* *}$ & $0.957^{* *}$ & $0.842^{* *}$ \\
\hline
\end{tabular}

*and ** mean significant at the 0.05 and 0.001 levels 


\section{d. Available Water Capacity (AWC) and Plant Available Water (PAW)}

The available water capacity is a soil characteristic of great importance, where it is a useful measure of the soil reserve of available water. It is defined as the amount of water held between its field capacity and permanent wilting point percentages (Hillel 2004). It is determined by number of factors, such as water content, potential relation for each soil layer, soil strength and bulk density, and soil depth (Brady and Weil, 2002). The total Plant Available Water is calculated by multiplying the AWC (expressed as an equivalent depth of water in $\mathrm{mm}$ per $\mathrm{m}$ depth of soil) by the plant's roots (D).

$\mathrm{PAW}=\left(\mathrm{FC}_{\mathrm{v}}-\mathrm{PWP}_{\mathrm{v}}\right)^{*} \mathrm{D}$

The concepts of AWC and PAW are useful for assessing the amount and frequency of water to be applied to crops under irrigation (Givi et al. 2004).
Under the dry land farming they determine how long a dry period the plants can tolerate.

Since the AWC is calculated by subtracting the FC and PWP, thus similar factors affect those parameters are observed for AWC, with different degrees of correlation coefficients (Table 3, 4 \& Fig. 2d). Because of silt and clay fractions favor occurrence of micro pores and menisci that generate capillary forces, so they correlated positively with AWC. Additionally silt and clay are working together to increase the specific area of the soil matrix and then the possibility of water adsorption (Hillel 2004). On the other hand the greater sand percent means denser soil, reducing total porosity leading to low water retention.

\section{e. Developing Pedotransfer Functions $\left(\mathrm{PTF}_{\mathrm{S}}\right)$}

With regards to the previous discussion, this confirmed the dependence of BD, FC, PWP and AWC on the soil texture with varying degrees of determination coefficients. A set of multivariate regression equations were obtained for them (Table 5).

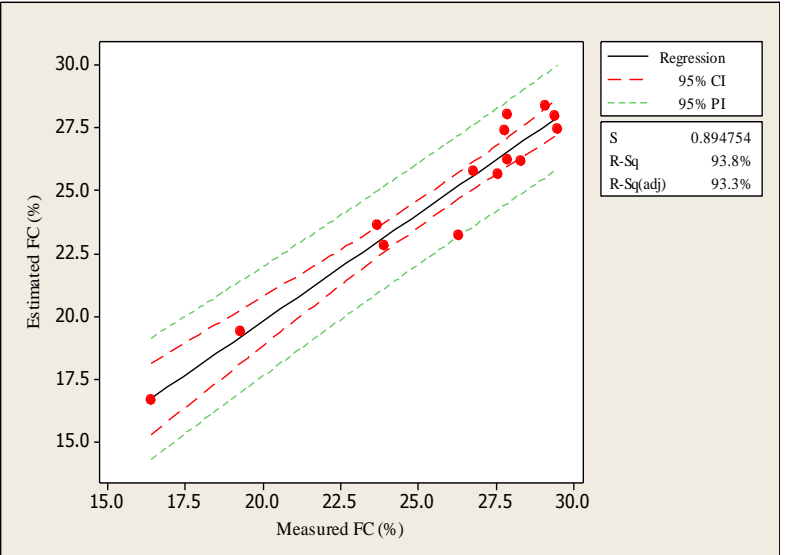

Fig. 2b. scatter plot of measured FC vs. estimated FC

Fig. 2a. scatter plot of measured BD vs. estimated BD

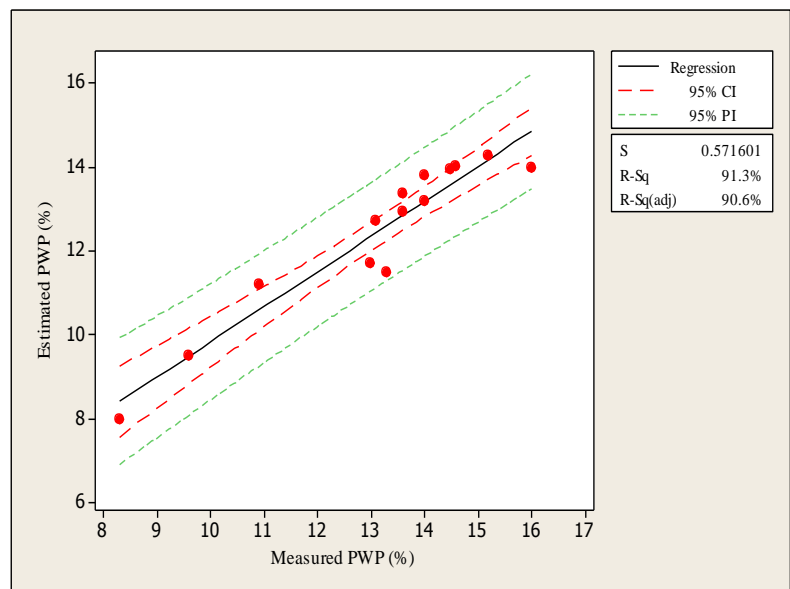

Fig. 2c. scatter plot of measured PWP vs. estimated PWP

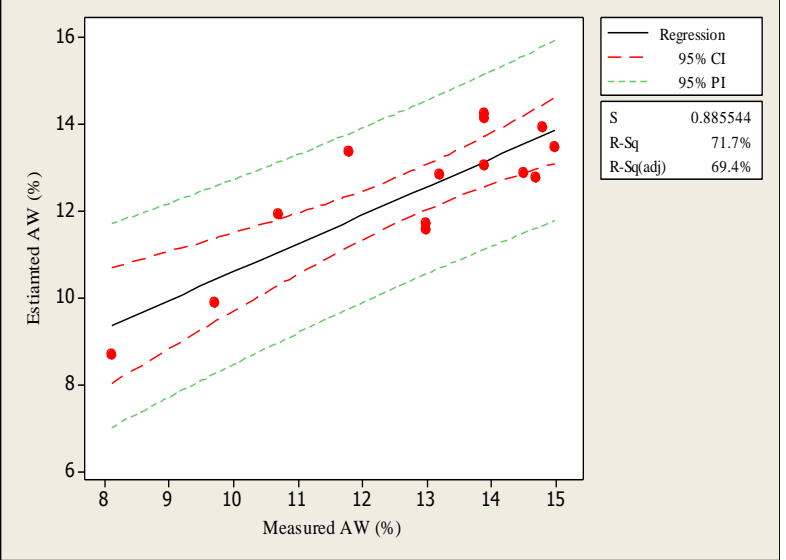

Fig. 2b. scatter plot of measured AWC vs. estimated AWC 
Table 4. linear regression analysis of the testing samples $(n=46)$

\begin{tabular}{|c|c|c|c|c|c|c|c|c|}
\hline \multirow{3}{*}{$\begin{array}{c}\text { Dependent } \\
\text { Variables }\end{array}$} & \multicolumn{8}{|c|}{ Linear regression analysis } \\
\hline & \multicolumn{2}{|c|}{ BD } & \multicolumn{2}{|c|}{ FC } & \multicolumn{2}{|c|}{ PWP } & \multicolumn{2}{|c|}{ AWC } \\
\hline & $\mathbf{R}^{2}$ & St. Error & $\mathbf{R}^{2}$ & St. Error & $\mathbf{R}^{2}$ & St. Error & $\mathbf{R}^{2}$ & St. Error \\
\hline Sand & $0.880^{* *}$ & 0.02 & $0.835^{* *}$ & 2.09 & $0.810^{* *}$ & 1.21 & $0.726^{* *}$ & 1.36 \\
\hline Silt & $0.763^{\text {** }}$ & 0.04 & $0.861^{* *}$ & 1.92 & $0.785^{* *}$ & 1.29 & $0.802^{* *}$ & 1.55 \\
\hline Clay & $0.361^{* *}$ & 0.07 & $0.244^{* *}$ & 4.48 & $0.287^{* *}$ & 2.34 & $0.166^{* *}$ & 2.37 \\
\hline $\mathrm{CaCO}_{3}$ & $0.707^{* *}$ & 0.05 & $0.598^{* *}$ & 3.26 & $0.595^{* *}$ & 1.76 & $0.506^{* *}$ & 1.82 \\
\hline $\mathrm{BD}$ & 1.00 & 1.00 & $0.766^{* *}$ & 2.49 & 0.747 & 1.39 & $0.661^{\text {** }}$ & 1.51 \\
\hline FC & & & 1.00 & 1.00 & $0.926^{* *}$ & 0.75 & $0.915^{* *}$ & 0.76 \\
\hline PWP & & & & & 1.00 & 1.00 & $0.709^{* *}$ & 1.40 \\
\hline
\end{tabular}

Table 5. The derived $\mathrm{PTF}_{\mathrm{S}}$ for estimating the BD, FC, PWP and AWC

\begin{tabular}{clcc}
\hline PTF $_{\mathbf{S}}$ NO. & \multicolumn{1}{c}{ Regression equation } & $\mathbf{R}_{\mathbf{p}}^{2}$ & St. Error \\
\hline 1 & $\mathrm{BD}=(0.995)+(0.00555 \mathrm{~S} \%)+(0.00158 \mathrm{Si} \%)+(0.00179 \mathrm{Cl} \%)$ & $88.4 \%$ & 0.029 \\
\hline 2 & $\mathrm{FC}=(3.45)+(0.0294 \mathrm{~S} \%)+(0.297 \mathrm{Si} \%)+(0.143 \mathrm{Cl} \%)$ & $88.4 \%$ & 1.780 \\
\hline 3 & $\mathrm{PWP}=(4.21)-(0.0170 \mathrm{~S} \%)+(0.116 \mathrm{Si} \%)+(0.0704 \mathrm{Cl} \%)$ & $83.1 \%$ & 1.169 \\
\hline 4 & $\mathrm{AWC}=(-0.76)+(0.0464 \mathrm{~S} \%)+(0.181 \mathrm{Si} \%)+(0.0722 \mathrm{Cl} \%)$ & $80.9 \%$ & 1.158 \\
\hline
\end{tabular}

\section{CONCLUSIONS}

It was found that the susceptibility of soils to be denser as the texture is coarser.

The clay and silt percentage had a positive correlation with soil water contents at FC, PWP and AWC, whereas the percentage of sand had a negative correlation with these hydraulic parameters. BD and calcium carbonate correlated negatively with FC, PWP and AWC, as result of an indirect effect as a sequence of interrelationships which exist among soil characteristics.

The effect of soil texture on the moisyure contents at FC and PWP can be expounded by the active surface area of the soil particles, and pore size distribution which control soil water retention.

The moisture content at different matric potentials is linearly correlated in this study.

BD, FC, PWP and AWC can be estimated by simple $\mathrm{PTF}_{\mathrm{s}}$ with judging acceptable $\mathrm{R}^{2}$, involving texture characteristics which may be both rapidly and cheaply determined by routine laboratory analysis. But, PTFs models are empirically, so they should be used with high attention to the environmental conditions when be applied to other regions.

\section{REFERENCES}

Archer J.R. and P.D. Smith, 1972: The relation between bulk density, available water capacity, and air capacity of soils. J. Soil Sci. 23:475-480.

Baker L., and D. Ellison, 2008: Optimization of pedotransfer functions using an artificial neural network ensemble method. Geoderma, 144:212-224.
Ben Mahmoud Kalid, 1995: Libyan Soils . National Authority for Scientific Research. Tripoli Bouma J., 1989: Using soil survey data for quantitative land evaluation. Advance Soil Science. 9:177-213.

Brady, N. C., and Ray R. Weil, 2002. The The Nature and Properties of Soils (13th Edition). Upper Saddle River, NJ: Prentice-Hall, Inc. pp: 210-212.

Bruno De Vos, Marc Van Miervenne, Paul Quataert, Jozef Deckers and Bart Muys, 2005: Predictive quality of Pedotransfer Functions for estimating bulk density of forest soils. Soil Sci. Soc. Am. J. , 69: 500-510.

Budiman Minasny and Alfred E.Hartemine , 2011 : Predicting soil properties in the Tropics. Earth-Science Review, Elsevier, 106: 52-62.

Duan Xingwu, Xie Yun, Liu Gang,Gao Xiaofei and LU Hongmei, 2010: Field Capacity in black soil region, northeast China. Chin. Geogra. Sci. 20:406-413.

Dzymala S., Z. Kaczmarek and W.Spychalski, 1995: Structure ability of fine textured red soils in North Libya. Int. Agrophysics, 9: 19-24.

Elfadki Khalid Ibrahim, 2009: Precipitation data of Libya. Libyan National Meteorological Center.

Foth D. Henry, 1978: Soil water; Fundamentals of soil science. John Wiley \& Sons.

Ghanbarian - Alavijeh B., and H. Millan, 2010: Point pedotransfer functions for estimating water retention curve. International Agrophysics., 24:243-251.

Givi J., S.O. Prasherb and R.M. Patel, 2004: Evaluation of pedotransfer functions in predicting the soil water contents at field capacity and wilting Point. Agriculture Water Management, 70:83-96.

Hillel Daniel, 2004: Introduction to environmental soil physics. Academic Press, USA. 
J.M.Hollis, J.Hannam and P.H.Bellamy, 2012: Empirically derived pedotransfer functions for predicting bulk density in European soils. European Journal of Soil Science. 63:96-109.

Kalman Rajkai, Sandor Kabos and M.Th. van Genuchten, 2004: Estimating the water retention curve from soil properties: Comparison of linear, nonlinear and concomitant variable methods. Soil \& tillage Research 79: 145-152.

Kishchuk B.E., 2000: Calcareous soils, their properties and potential limitations to conifer growth in Southeastern British Columbia and Western Alberta: A literature review, Information Report NOR-X-370. Canadian Forest Service, Northern Forestry Centre.

Klute A., 1986a: Method of soil Analysis. Part 1- physical and mineralogical methods. 2nd edition'. (Ed A .Klute) (American Society of Agronomy Inc.: Madison, WI).

Klute A., 1986b: Method of soil Analysis. Part 2- Chemical and Biochemical methods. 2nd edition'. (Ed A. Klute) (American Society of Agronomy Inc.: Madison, WI).

Lal R., 2006: Encyclopedia of Soil Science. State of Florida, USA: Taylor \& Francis, 218-222.

Oyedele D.J. and F.O.Tijani, 2010: Spatial and temporal variability of soil water. Int. Agrophysics, 24 : 171-176.

Pachepsky Y.A. and W.J. Rawls, 1999: Accuracy and reliability of pedotransfer functions as affected by grouping soils. Soil Sci. Soc. Am. J., 63:1748-1757.
Saxton K.E., W.J. Rawls, J.S. Romberger, and R.I. Papendick, 1986: Estimating generalized soil water characteristics from texture. Soil Sci. Soc. Am .J., 50:1031-1036.

Selkhozprom Export. Soil Ecological Expedition , 1980 : Soil studies in the western zone, the eastern zone, and the pasture zone of Libya. Ministry of Agri. , Reclamation and land development. Tripoli.

Troeh R. Frederick and Louis M. Thompson, 2005: Soils and soil fertility. Sixth edition, Wiley-Blackwell.

Van den Berg, M. Klamt, Van Reeuwijk L.P. and W.G. Sombroek, 1997: Pedotransfer functions for estimation moisture retention characteristics of Ferrasols and related soils. Geoderma 78: 161-180.

Walczak R., B.Witkowska-Walczak, and C.Salawinski , 2002: Comparison of correlation models for the estimation of the water retention characteristics of soil. International Agrophysics.16:79-82.

Wosten, J. H. M., Y.A. Pachepsky and W.J. Rawls, 2001: Pedotransfer functions: bringing the gap between available basic soil data and missing soil hydraulic characteristics. J . of Hydrology. 251:123-150.

Zacharias Steffen and Gerd Wessolek, 2007: Excluding Organic Matter content from Pedotransfer Predictors of soil water retention. SSSAJ, volume 71: Number 1. January - February.

Zhuang J., Y. Jin, and T. Miyazaki, 2001: Estimating water retention characteristics from soil particle-size distribution 


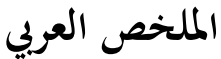

التنبؤ بالكثافة الظاهرية والثوابت المائية لبعض الترب الليبية الجيرية بإستخدام التوزيع الحجمي

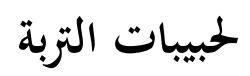

أحمد يوسف هبيل

لتحقيق هذا الغرض، تم بتميع 46 عينة تربة كمجموعة اشتقاق

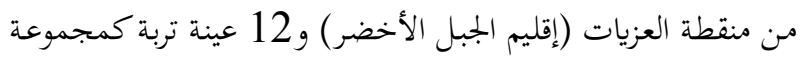
إختبار من منقطة المخيلي التي تتصف بظروف بيئية مشابهة لمنقطة العمل. تتصف معادلات الانحدار المحققة بمعاملات تحديد تنبؤية

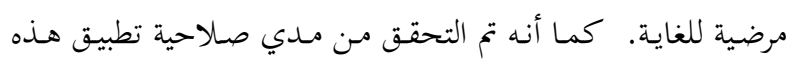

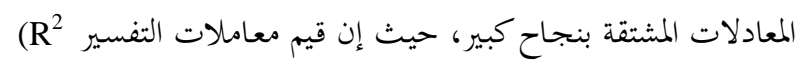

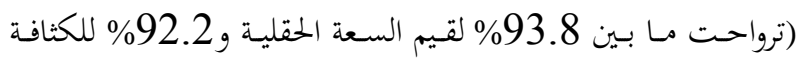
الظاهرية و91.3\% لنقطة الذبول الدائم و71.7\% لقيم سعة الماء

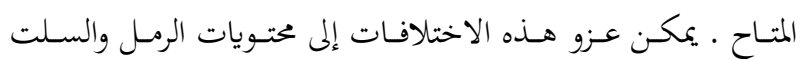
بدرجة أكبر من محتوي الطين في العينات تحت الاختبار.
إن معظـم معــادلات الانهـدار المطـورة لتقـــير الكثافـة الظاهريـة

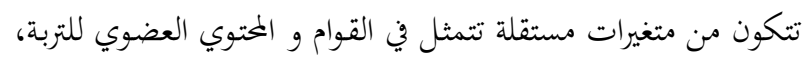
وفي الوقت نفسـه نجـد أن غالبيـة المعـادلات التي تم نشـرها وتـداولها للتنبؤ بقيم ثوابـت المحتوي الرطوبي تتضـمن القوام والكثافة الظاهرية

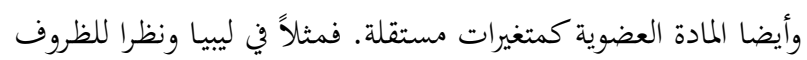

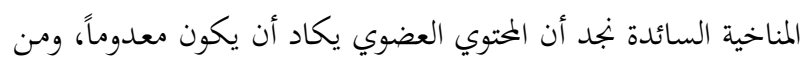

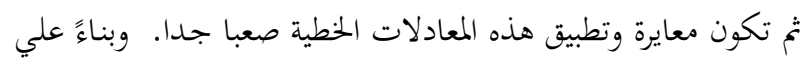
ذلك، فإن الهدف من هذا العمل هو دراسة العلاقات المتبادلة مابين

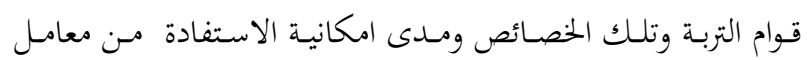
الترابط بهدف تطوير معادلات إنحدار بغرض توفير الوقت في تقدير الكثافة الظاهرية وثوابت الرطوبة الأرضية من البيانات المتاحة روتينيا مثل قوام التربة كعامل مستقل في المعادلة. 